\title{
Evaluasi Penggunaan Tepung (Batang+Daun) Tanaman Kenikir (Cosmos Caudatus Kunth) sebagai Feed Additive terhadap Kualitas Internal Telur Ryam Ras Petelur
}

\section{Maria Selfiana Pasi ${ }^{\mathrm{a}}$, Irfan H. Djunaidi ${ }^{\mathrm{b}}$, M. Halim Natsir ${ }^{\mathrm{c}}$ \\ ${ }^{a}$ Fakultas Pertanian, Universitas Timor, Kefamenanu, TTU - NTT, 85613, Indonesia, email: selfianapasi@gmail.com \\ ${ }^{b}$ Fakultas Peternakan, Universitas Brawijaya, Malang - JawaTimur, 85613, Indonesia, email: irjuna@gmail.com}

${ }^{c}$ Fakultas Peternakan, Universitas Brawijaya, Malang - JawaTimur, 85613, Indonesia, email: emhanatsir@ub.ac.id

\section{Article Info}

Article history:

Received 29 April 2021

Received in revised form 30 April 2021

Accepted 01 Mei 2021

DOI:

https://doi.org/10.32938/ja.v6i2.1365

\section{Keywords:}

Kenikir

Feed Additive

Kualitas Internal Telur

Ayam petelur

\section{Abstrak}

Tujuan penelitian ini adalah untuk mengevaluasi pengaruh penggunaan tepung (batang+daun) tanaman kenikir terhadap kualitas internal telur ayam ras petelur. Penelitian ini telah dilakukan di Desa Bacem, Kecamatan Sutojayan, Kab. Blitar. Penelitian ini menggunakan metode eksperimen dengan desain Rancangan Acak Lengkap (RAL) terdiri atas 4 perlakuan dan 6 ulangan. Perlakuan P0 = Pakan basal $+0 \%$ tepung (batang+daun) kenikir, P1 $=$ Pakan basal $+0,25 \%$ tepung (batang+daun) kenikir, P2 $=$ Pakan basal $+0,50 \%$ tepung (batang+daun) kenikir, P3 $=$ Pakan basal $+0,75 \%$ tepung (batang+daun) kenikir. Parameter yang diamati adalah berat putih telur, proporsi putih telur, berat kuning telur, proporsi kuning telur dan skor warna kuning telur. Hasil penelitian menunjukkan bahwa pemberian tepung (batang+daun) tanaman kenikir sebagai feed additive dapat memberikan pengaruh sangat nyata $(\mathrm{P}<0,01)$ terhadap berat putih telur, dan tidak berpengaruh nyata $(\mathrm{P}>0,05)$ terhadap proporsi putih telur, Berat kuning telur, proporsi kuning telur dan skor warna kuning telur. Dari hasil penelitian ini dapat disimpulkan bahwa pemberian tepung (batang+daun) kenikir sebagai feed additive pada taraf $0,75 \%$ berpengaruh terhadap kualitas internasl telur.

\section{Pendahuluan}

Salah satu sumber protein hewani yang dapat memenuhi kebutuhan gizi manusia adalah telur. Oleh karena itu usaha peternakan terkuhususnya usaha ayam petelur memiliki potensi yang cukup besar untuk dikembangkan. Telur mempunyai protein yang tinggi, sehingga sangat cocok untuk memenuhi kebutuhan manusia untuk pertumbuhan, disamping mudah dicerna, mudah didapat, dan porto terjangkau oleh kalangan masyarakat.

Konsumsi protein hewani berupa telur semakin meningkat karena peningkatan jumlah penduduk dari tahun ketahun semakin meningkat pula tingkat ekonomi masyarakat. Semakin tinggi pendapatan seseorang, menyebabkan pergeseran pola konsumsi dari karbohidrat oriented menjadi protein oriented. Dari sinilah para peternak harus dituntuk untuk memproduksi telur dengan memperhatikan kualitas internal telur karena telur dengan kandungan lemak yang tinggi berpengaruh pada kesehatan manusia.

Kualitas internal telur menjadi salah satu faktor perhatian penting untuk konsumen. Faktanya konsumen tidak menyukai putih telur yang memiliki bercak darah, kuning telur yang memilki lemak tinggi dan memliki warna kuning telur yang pucat. Akan tetapi permasalahan tersebut belum dapat teratasi. Oleh karena itu salah satu alternatif dari permasalahan tersebut adalah dengan penambahan feed additive dari tepung (batang+daun) tanaman kenikir (Cosmos caudatus Kunth). Kenikir memiliki senyawa bioaktif yang berkhasiat sebagai antibakteri dapat memperbaiki kualitas internal telur yaitu dengan mengurangi lemak dalam kuning telur serta dapat menghambat bakteri patogen yang ada dalam telur.

\section{Metode Penelitian}

\subsection{Waktu dan Tempat}

Penelitian ini telah dilaksanakan di Desa Bacem, Kecamatan sutojayan, Kab. Blitar. Penelitian berlangsung selama 5 minggu terhitung dari 26 November 2018 - 06 Januari 2019

\subsection{Materi Penelitian}

Bahan-bahan yang digunakan dalam penelitian ini meliputi: Pakan yang terdiri dari Jagung, Bekatul, Meat Bone Meal, CPO, DCP, UB feed, tepung batu, menir batu, Sodium bikarbonat dan feed additive (tepung kenikir), Ternak yang dipakai dalam penelitian ini adalah ayam petelur Strain Hy-Line Brown umur 35 minggu sebanyak 240 ekor. Peralatan penelitian yang digunakan dalam penelitian ini : Kandang sistem battery, Kabel dan Lampu, Pipa paralon, Tempat pakan, Tempat minum, Terpal, Gayung, Ember Egg tray, Sapu, Timbangan digital, Jangka sorong, Alat tulis.

\subsection{Metode Penelitian}

Penelitian ini menggunakan metode eksperimental dengan menggunakan Rancangan Acak Lengkap (RAL) yang terdiri dari 4 perlakuan dan 6 kali ulangan terdapat 24 unit percobaan, setiap unit diisi 10 ekor ayam petelur, perlakuan adalah pakan yang menggunakan level pemakaian tepung (batang+daun) tanaman kenikir hasil terbaik pada penelitian tahap pertama. Perlakuan yang diberikan terdiri dari :

$$
\begin{aligned}
& \mathrm{P} 0=\text { Pakan basal }+0 \% \text { tepung (batang+daun) kenikir } \\
& \mathrm{P} 1=\text { Pakan basal }+0,25 \% \text { tepung (batang+daun) kenikir } \\
& \mathrm{P} 2=\text { Pakan basal }+0,50 \% \text { tepung (batang+daun) kenikir } \\
& \mathrm{P} 3=\text { Pakan basal }+0,75 \% \text { tepung (batang+daun) kenikir }
\end{aligned}
$$

Prosedur pemberian pakan perlakuan yaitu pakan perlakuan dicampur dengan pakan basal sampai homogen lalu diberikan pada ternak penelitian. Jumlah pemberian pakan yang diberikan yaitu $125 \mathrm{~g} / \mathrm{ekor} / \mathrm{hari}$.
Prosedur Pengukuran kualitas internal telur ayam yang diamati adalah berat putih telur, proporsi putih telur, berat kuning telur, proporsi kuning telur dan skor warna kuning telur.

a. Berat putih telur

Berat putih telur diperoleh dengan cara memecahkan telur dan memisahkan putih telur dengan kuning telur kemudian putih telur ditimbang untuk mengetahui berat putih telur.

b. Proporsi putih telur

Proporsi Putih Telur (\%) di peroleh dengan menimbang putih telur dan dilakukan penghitungan dengan membagi bobot putih telur dengan bobot telur dan di kalikan 100\% (Djaelani, 2016).

Proporsi putih telur $=$ Berat albumen $(\mathrm{g})$ X $100 \%$

Bobot telur $(\mathrm{g})$

c. Berat kuning telur

Berat kuning telur diperoleh dengan memecahkan telur kemudian memisahkan putih telur dan kuning telur lalu kuning telur ditimbang untuk mengetahui berat kuning telur.

d. Proporsi Kuning Telur (\%) diperoleh dengan cara memisahkan kuning dan putih telur terlebih dahulu kemudian kuning telur ditimbang dan dilakukan penghitungan dengan membagi bobot kuning telur dan di kalikan $100 \%$ (Djaelani, 2016).

Proporsi kuning telur = Berat kuning telur $(\mathrm{g}) \mathrm{X} 100 \%$ Berat telur $(\mathrm{g})$

e. Skor warna kuning telur, yang di amati dan diukur dengan egg roche yolk colour fan yang mempunyai kisaran nilai 1-15 (Sahara, 2010). Telur yang di amati diambil secara acak pada tiap perlakuan.

\section{Hasil dan Pembahasan}

Kualitas internal telur merupakan salah satu faktor perhatian penting untuk konsumen. Faktanya konsumen tidak menyukai putih telur yang memiliki bercak darah, kuning telur yang memiliki lemak tinggi dan memiliki warna kuning telur yang pucat. Kualitas telur adalah istilah umum yang mengacu pada beberapa standar yang menentukan kualitas internal. Kualitas internal mengacu pada putih telur (Albumen), warna dan berat kuning telur. Nilai rerata kualitas internal telur dapat dilihat pada Tabel 1 .

Tabel 1. Nilai rerata Berat putih telur (BPT), Proporsi putih telur (PPT), Berat kuning telur (BKT), Proporsi kuning telur (PKT) dan Skor warna kuning telur

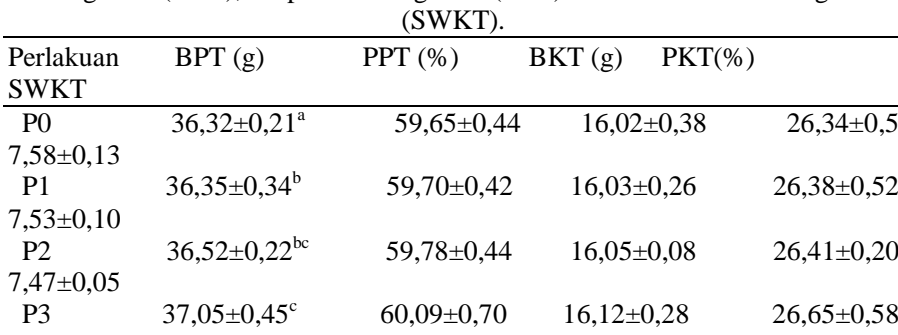

$7,42 \pm 0,12$

Keterangan: Superskrip yang berbeda pada kolom yang sama menunjukkan perbedaan nyata $(\mathrm{P}<0,01)$

\subsection{Berat dan Proporsi Putih Telur}

Albumen (Putih telur) merupakan salah satu bagian dari sebuah telur utuh yang mempunyai persentase sekitar 58-60\% dari berat telur dan mempunyai dua lapisan, yaitu lapisan kental dan lapisan encer King'ori (2012). Bell and Weaver (2002), melaporkan bahwa lapisan kental terdiri atas lapisan kental dalam dan lapisan kental luar dimana lapisan kental dalam hanya 3\% 
dari volume total putih telur dan lapisan kental putih telur mengandung protein dengan karakteristik gel yang berhubungan dengan jumlah ovomucin protein.

Nilai rerata hasil perhitungan data berat putih dan proporsi putih telur selama penelitian dari yang tertinggi sampai terendah adalah sebagai berikut (P0) 36,32 $\pm 0,21$, (P1) 36,35 $\pm 0,34$, (P2) 36,52 $\pm 0,22$, dan (P3) 37,05 $\pm 0,45$ (g) dan proporsi putih telur adalah (P0) 59,65 $\pm 0,44$, (P1) 59,70 $\pm 0,42$, (P2) $59,78 \pm 0,44$, dan (P3) 60,09 $\pm 0,70(\%)$. Hasil perhitungan uji Jarak Berganda Duncan's menunjukkan bahwa rerata berat putih telur antar perlakuan berbeda sangat nyata $(\mathrm{P}<0,01)$. Peningkatan berat putih telur pada penelitian ini karena adanya keseimbangan zat pakan yaitu sumber energi dan protein dalam pakan maupun dari fitobiotik tepung kenikir sehingga terserap dalam pembentukan putih telur sehingga berat putih telur dari setiap perlakuan meningkat. Sesuai pendapat Argo et al. (2013) melaporkan bahwa kecil besarnya berat putih telur dipengaruhi oleh sumber protein yang berasal dari pakan maupun dari fitobiotik yang digunakan dalam campuran pakan. Bahan pakan yang memiliki kandungan protein yang tinggi dapat meningkatkan protein didalam putih telur. Putih telur (Albumen) hampir sebagian besar tersusun dari 86,8\% air. Konsumsi air minum berpengaruh terhadap jumlah volume telur yang dihasilkan karena sebagian besar penyusun putih adalah air.

Bahan pakan yang memilki kandungan protein yang tinggi menyumbangkan protein yang tinggi pula didalam putih telur. Asam amino terdiri dari asam amino essensial dan asam amino non essensial, metionin termasuk asam amino essensial. Salah satu contoh pengaruh suplementasi terhadap produksi dan kualitas telur ditunjukkan oleh penelitian Amrullah (2003), dimana ayam yang diberi $0,1 \%$ metionin dalam $14 \%$ dan $16 \%$ protein kasar di ransumnya ternyata memiliki kualitas telur yang lebih baik (bobot telur) dan produksi yang lebih tinggi (Hen Day Production) dibanding yang tidak diberi suplementasi.

\subsection{Berat dan Proporsi Kuning telur}

Bagian yang paling penting pada isi telur adalah kuning telur. Protein paling tinggi terdapat pada bagian kuning telur. Tinggi rendahnya persentase berat kuning telur yang dihasilkan tergantung dari konsumsi ransum dan tingkat kecernaan terhadap ransum tersebut terutama kandungan protein dan lemak.

Nilai rerata hasil perhitungan data berat dan proporsi kuning telur selama penelitian dari yang tertinggi sampai terendah adalah sebagai berikut (P0) 16,02 $\pm 0,38$, (P1) 16,03 $\pm 0,26$, (P2) 16,05 $\pm 0,08$, dan (P3) 16,12 $\pm 0,28$ (g), dan proporsi kuning telur dari terendah sampai tertinggi adalah (P0) 26,34 $\pm 0,51$, (P1) 26,38 $\pm 0,52$, (P2) 26,41 $\pm 0,20$, dan (P3) 26,65 $\pm 0,58$ (\%). Hasi uji Jarak Berganda Duncan's menunjukkan bahwa rerata berat kuning telur dan proporsi kuning telur antar perlakuan tidak berbeda nyata $(\mathrm{P}>0,05)$. Penurunan berat kuning telur dan proporsi kuning telur pada penelitian ini karena terkait dengan fitobiotik pada kenikir mengandung serat kasar tinggi sehingga interaksi antara serat mengikat lemak dan akhirnya ikut terbuang dengan ekskreta. Kandungan dari zat flavonoid dari kenikir berperan dalam mensintesis lemak sehingga lemak tidak ikut terserap oleh kuning telur. Sesuai pendapat Deko et al. (2018), melaporkan bahwa penurunan berat kuning telur kemungkinan diakibatkan oleh karena adanya kandungan flavonoid pada umbi dan kulit bawang putih berupa myricetin, quercetin, kaempferol dan apigenin berperan dengan baik dalam sintesis lemak, sehingga lemak tidak terserap pada kuning telur melainkan dimanfaatkan untuk energi dalam berproduksi. Figueiredo et al. (2012), menjelaskan bahwa penambahan flavonoid berupa quercetin dalam pakan dapat meningkatkan laying rate, egg shell strength, kandungan protein telur dan haugh unit serta menurunkan kandungan lemak pada kuning telur, sehingga berat pada kuning telur menjadi menurun.

\subsection{Skor warna kuning telur}

Egg yolk colour fan merupakan alat pengukuran skor warna kuning telur yang dilakukan dengan cara mencocokkan warna kuning telur dengan warna standar yang terdapat pada kipas kuning telur (Egg yolk colour fan). Beberapa faktor yang mempengaruhi warna kuning telur adalah Xanthophyll, strain, varietas kandang, kesehatan, bahan tambahan pakan dan rasio telur perjumlah makanan.

Nilai rerata hasil perhitungan data skor warna kuning telur selama penelitian dari yang tertinggi sampai terendah adalah sebagai berikut (P0)


Berganda Duncan's menunjukkan bahwa rerata skor warna kuning telur antar perlakuan tidak berbeda nyata $(\mathrm{P}>0,05)$. Perbedaan tidak nyata terhadap skor warna kuning telur ini kemungkinan karena pakan yang diberikan mengandung karoten yang sama. Hal ini berbanding terbalik dengan pendapat dari Argo et al. (2013), melaporkan bahwa pemberian Azolla microphylla dalam pakan yang memiliki Xanthophyll pada level yang berbeda pada ayam arab petelur meningkatkan warna kuning telur. Garba et al. (2010), menjelaskan bahwa apabila pemberian pakan sumber energi (jagung) berbeda level pada setiap perlakuan maka akan meningkatkan skor warna kuning telur, peningkatan skor warna kuning telur karena dari bahan pakan jagung mengandung karotenoid. Golongan pigmen yang larut dalam lemak disebut karotenoid, oleh karena itu penyerapan karoten sangat dipengaruhi oleh lemak yang terkandung dalam pakan. Leeson dan Summer, (2001) melaporkan bahwa skor warna kuning telur meningkat seiring dengan penambahan pakan mengandung sumber karoten dalam pakan. Sumber utama energy pada penelitian ini berasal dari pakan jagung kuning. Jagung kuning mengandung Xanthophyll yang merupakan pigmen kuning hingga orange yang dapat memberikan warna pada kuning telur.
Campuran ransum pada penelitian ini berupa jagung kuning proporsi jagung pada semua perlakuan yang diberikan relatif sama sehingga kandungan karoten antar perlakuan tidak berbeda maka tidak menyebabkan terjadinya peningkatan pada warna kuning telur. Castellini et al. (2006) melaporkan bahwa salah satu faktor yang mempengaruhi skor warna kuning telur adalah sistem pemeliharaan yang berbeda yaitu pemeliharaan secara organik dan konvensional, pemeliharaan dengan cara organik menunjukkan memberikan skor warna kuning telur yang lebih baik karena ayam diberi kebebasan untuk memakan rumput. Kandungan karotenoid dalam rumput lebih tinggi sehingga skor warna kuning telur yang dihasilkan meningkat.

\section{Simpulan}

Penggunaan tepung (batang+daun) tanaman kenikir (Cosmos caudatus Kunth) pada taraf $0,75 \%$ sebagai feed additive meningkatkan Penampilan Produksi dan Kualitas Telur Ayam Ras Petelur yang optimal.

\section{Daftar Pustaka}

Argo, L. B. , Tristiarti dan Mangisah, I. 2013. Kualitas Telur Ayam Arab Petelur Fase I dengan Berbagai Level Azolla Microphylla. Animal Agricultural Journal. 2(1): 445-447.

Bell, D., and Weaver. 2002. Commercial chicken meat and Egg. Kluwer Academic Publishers. United States of America

Castellini, C., Perella, F., Mugnai, C., and Dal Bosco, A. 2006. Welfare, productivity and quality traits of egg in laying hens reared under different rearing systems. National Journal of Animal Science. 54 (2): $147-155$.

Deko, M. K., Djunaidi, I. H., and Natsir, M. H. 2018. The Use of Garlic (Allium sativum Linn) Bulb and Husk Powder as an Organic Feed Additive on Egg Quality of Laying Hens. International Research Journal of Advanced Engineering and Science, 3 (3): 218 - 222.

Edi, D. N., Natsir, M. H., and Djunaidi, I. H. 2018. The Effect of Dietary Teak Leaf Extract (Tectona grandis Linn. $f$ ) on Egg Quality of Laying Hens. Scholars Journal of Agriculture and Veterinary Sciences (SJAVS). Sci., 5(9): 490-497

Figueiredo, G. O., A.G. Bertechini, E.J., Fassani, P.B., Rodrigues, J.Á.G., Brito, S.F., and Castro. 2012. Performance And Egg Quality Of Laying Hens Fed With Dietary Levels Of Digestible Lysine And Threonine. Arq. Bras. Med. Vet. Zootec. 64(3):743-750.

Garba, S., Jibir, M., and Omojola AB. 2010. Egg quality of commercial hens fed diet fed with increasing substitution level of metabolizable energy of pearl millet for corn. Proceeding 35th Conference of Society of Animal Production, Ibadan (Nigeria): University of Ibadan. 308-310.

King'ori, A. M. 2012. Uses of poultry egg: Egg albumen and egg yolk. $J$. Poultry. Sci, 5 (2): 9-13

Leeson, S, \& J. D. Summers. 2005. Comercial Poultry Nutrition 3rd Edition. Publ. Nottingham University Press, England. 